\title{
A mythological reading of Cicero's Pro Sex. Roscio Amerino
}

\author{
Dr. Allam, M. Reda K. \\ Faculty of Arts- Ain Shams University
}

This paper intends to investigate how for was the influence of the Greek myth in the text of Cicero's first criminal defense speech: Pro Sex. Roscio Amerino, which has been recognized by the linguists and classicists alike as being outstanding and enchanting specimen of dramatic Latin literature. It is an excellent exemplar of Cicero's interest in weaving Greek mythical tales and characters into the dramatic texture of his forensic speeches. It deals with the insertion of the Greek myth as one of Cicero's characteristic, vivid rhetorical methods of persuasion and effect upon his elite audience ${ }^{1}$, i.e., the senatorial jurors who were convoked in the criminal court (quaestio perpetua) ${ }^{2}$ to examine the murder case of Sex. Roscius Amerinus; those jurors were eagerly enthusiastic and interested in the literature and philosophy ${ }^{3}$. Cicero prided himself when he was old on having had the courage, to plead his first murder case of Sextus Roscius Amerinus (80 B. C.), and won it against Chrysogonus, the most powerful freedman and favourite of the dictator Sulla, though he was still young man, and of less experience; this attack on Chrysogonus was in reality a veiled attack on Sulla himself ${ }^{4}$. He also stated that after the good defense of Sex. Roscius Amerinus there was no case to which he was thought to be unequal ${ }^{5}$. I am going to clarify that Cicero had not won this most famous murder case out of his legal shrewdness, but out of his literary and rhetorical artistry $^{6}$ because in this speech he focused on the insertion of the Greek myth and its mythical heroes and heroines mentioned in the literatures and dramas of both Greeks and Romans, especially when he attempted to refute the accusation of parricide cast upon his client, Sextus Roscius Amerinus ${ }^{7}$. 
A mythological reading of Cicero's Pro Sex.

Intertextual allusions existed in our speech of Sextus Roscius Amerinus had their extant origins in some famous ancient Greek and Roman authors of both poetry and prose (like Aeschylus, Sophocles, Euripides, Aristophanes, Thucydides, Cicero, Vergilius and Tacitus), who intensively and carefully adapted the Greek myth mentioned by the most illustrious epic poet Homer, and handled it in an elaborate way reconsidering Aristotelian "Poetics" and their well-known compositional schemes ${ }^{8}$.

\section{Various intertextual uses of the Greek myth.}

The Greek myth had been adapted by the ancient Greek and Roman authors as a means of persuasion, effect, and an assertion to some point of view; and it had been introduced in a form of indirect statements ${ }^{9}$. The dramatic illusion of the Greek myth ${ }^{10}$ was based on both the author and his public $^{11}$. Bain reassures that the dramatic illusion of the Greek tragedy of Aeschylus, Sophocles and Euripides involved myth had a complete, deep effect on the feelings of the public ${ }^{12}$. The influence of the Greek myth was very apparent in the "Histories" of Thucydides, especially when he mentioned the letter sent to the Athenians by the Athenian leader of the expedition to Sicily which in fact, according to the commentators, coincides with the speech delivered before the Argives (the Greeks) by Agamemnon, the leader of the Greek expedition to Troy ${ }^{13}$. We may also observe the effect of Homer on Vergilius who described in his "Aeneid" the mythical Greek island "Crete" in the mouth of Anchises, father of Aeneas (Greta Iovis magni medio iacet insula ponto) ${ }^{14}$; this effect appears also in the "Histories" of Tacitus who recorded to us the impressive speech held in the senate by the emperor Vitellius in 69 A.D which reflects the gloomy atmosphere existed in the funeral of Patroclus ${ }^{15}$, a friend of Achilles, who was slain before Troy by Hector, son of Priamus, king of Troy.

\section{Cicero's motives of adapting the Greek myth.}

Modern scholarship has resolved that Cicero's qualities such as his rhetorical schemes and careful delineation of his own persona ${ }^{16}$ had enabled him to claim victory ${ }^{17}$ based on the murder case of Sex. Roscius Amerinus, 
which was weak ${ }^{18}$ and lacking both convincing materials and plausible strong, legal proofs because it had been argued on grounds of relative probability ${ }^{19}$, and not on facts ${ }^{20}$.

In this forensic speech Cicero sought to convince the jurors that he had no political motives; his general tactic of defense depended upon the reinterpretation of the prosecution's characterization of the defendant, towncountry stereotypes and class- snobbism ${ }^{21}$; and in order to support his point of view he demonstrated some patriotic themes, literary and philosophical quotations as to dazzle the educated jurors. It is remarkable that Cicero occasionally began some of his judicial speeches by praising his educated, cultivated audience ${ }^{22}$.

Moreover, he cited in some of his rhetorical writings that the ideal or perfect orator must be equipped with culture, and also must be acquainted with knowledges of philosophy, history and laws ${ }^{23}$.

Cicero was so admirably and affectionately touched by both Greek and Roman literatures that he occasionally quoted many verses from the well-known ancient Greek and Roman epic poets, and mentioned some in his rhetorical and philosophical writings, but too little in his forensic speeches ${ }^{24}$. Boyle ${ }^{25}$ records that "Cicero had no problem in reading second century Roman comedy (Rosc. Amer. 46- 7), and tragedy as a mirror of his Roman world". Quintilianus ${ }^{26}$ cited that the charm of the poetry could soothen and lessen the roughness of the oratory, and that the true feelings of the poets had been always found to confirm the proofs of the advocate in his defense. Moreover, Cicero used to insert the Greek myth adapted by both Greek and Roman Dramas, in his orations and forensic speeches ${ }^{27}$; for instance, he quoted from Ennius' Medea $^{28}$ in his speech (Pro. Leg. Man. 22) when he compared Mithradates with Medea who had slaughtered her brother and thrown his members into the air to hinder her father from following her; and also in his speech (Rab. Post. 29) when he appeals to his jury's knowledge of the behaviour of kings. Our present speech of Roscius

Amerinus had been elaborately and rhetorically constructed, and based 110 
= A mythological reading of Cicero's Pro Sex.

on Cicero's discreet insertion of the Greek myth, especially while refuting the charge of parricide in the part of his defense ${ }^{29}$.

\section{Cicero's discreet insertion of the Greek myth.}

Cicero (Pro Rosc. Amer. 66) referred to the most famous mythical tales of the two sons who committed a parricide: the first called Orestes ${ }^{30}$ who killed his mother Clytemnestra to average the murder of his father; the other called Alcmaeon ${ }^{31}$ who murdered his mother at the wish of his father, and with the approval of the oracle. Both of them were harassed and terrified by the mythical avenging Erinnyes (Furiae), the representatives of divine justice, who had driven them to madness:

Pro Rosc. Amer. 66:

"cum paresertim deorum immortalium iussis atque oraculis id fecisse dicantur, tamen ut eos agitent Furiae neque consistere umquam patiantur, quod ne pii quidem sine scelere esse potuerunt".

Cicero (Pro Rosc. Amer. 67) quoted from the Attic orator, Aischines (Timarchus 190- 1) ${ }^{32}$, the idea of the mythical avenging Erinnyes (Furiae) who pursue the parricides to avenge their murders ${ }^{33}$, and prosecute them before the judgment- seat of the goddess Athene, to whom the Erinnyes submit the award. He mentioned in this quotation that the Furiae appear in the darkness ${ }^{34}$ and hold the blazing torches, and never leave the wicked night and day; and they always dwell in their hearts:

Aisch. Tim. 190- 191:

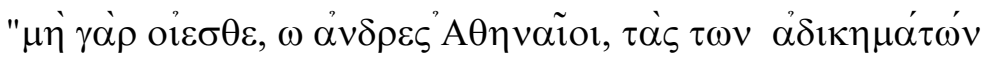

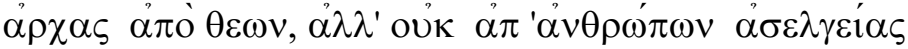

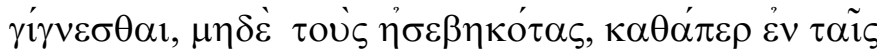

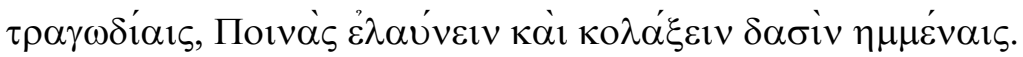

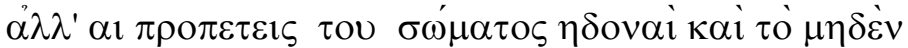


ב Allam. M. Reda K.

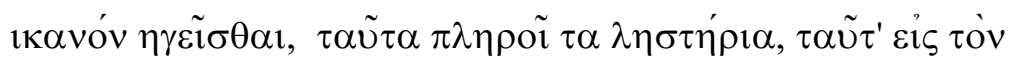

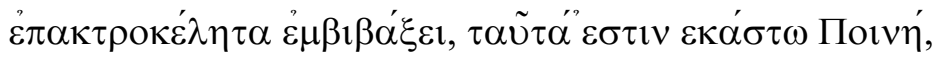

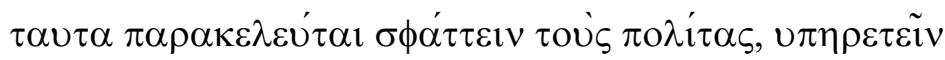

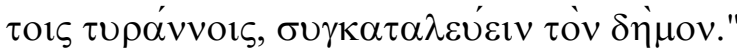

Cic. Pro Rosc. Amer. 67:

"Nolite enim putare, quem ad modum in fabulis saepenumero videtis, eos, qui aliquid impie scelerateque commiserunt agitari et perterreri Furiarum taedis ardentibus. Sua quemque fraus et suus terror maxime vexat, suum quemque scelus agitat amentiaque adficit, suae malae cogitationes conscientiaeque animi terrent; hae sunt impiis assiduae domesticaeque Furiae, quae dies noctesque parentium poenas a consceleratissimis filiis repetant".

The myth of Orestes had been considered as a mimesis of the mimesis because it could reflect its art and influence upon both the Greek tragedy of Aeschylus, Sophocles and Euripides, and the Roman tragedy of Ennius. Segal cites that Sophocles depended geniously and craftly upon the myth of Orestes mentioned by Aeschylus ${ }^{35}$. Zeitlin and Erbse refer to the various uses of the intertextuality found in the Orestes of Euripides and how his public had to learn more and more the works of Homer, Aeschylus and Sophocles as to grasp his keen allusions ${ }^{36}$.

It is quite probable that Cicero learnt in the lessons of rhetoric which he had attended while he was young-both the myth of Orestes as a tragic $\operatorname{plot}^{37}$ and the idea of the avenging Erinnyes as a symbol of self-reproach and stings of conscience which he produced again in a plausible, political interpretation ${ }^{38}$. Skard reassured that Cicero was the first Roman writer who could figuratively produce the mythical avenging Erinnyes ${ }^{39}$, and stated that the ancient Roman tragedy (Orestes) was a very important factor that helped Cicero to develop the significance of the conscience because the Roman public in Cicero's time was acquainted with the avenging Erinnyes INV 
presented by that well-known Roman masterpiece, and was also prepared to accept anything about it from Cicero ${ }^{40}$.

Cicero reassured the prosecutor Erucius ${ }^{41}$ that he would not withdraw from the court, and compared it with the battlefield by referring to some battles ${ }^{42}$ in which some warriors had been wounded, and others had withdrawn only because of their old age. He also quoted a verse from the (Achilles) of the illustrious Roman epic writer, Ennius ${ }^{43}$, referring to many wounded Greeks; this verse was spoken by Ulysses, when excusing himself to Ajax for having taken refuge in the tent of Achilles, after the mythical Trojan general, Hector had fired the Greek ships:

Pro Rosc. Amer. 90:

"Quis ibi non est vulneratus ferro Phrygio"44

Cicero also mentioned Priamus ${ }^{45}$, the king of Troy who had been hindered to fight because of his old age, as it had been referred to in the Iliad; and the Romans had employed his name to describe an old man:

Pro Rosc. Amer. 90:

"Postremo Priamum ipsum senem"

When Cicero tried to bring suspicion in regard to the murder of Sextus Roscius, he related to the jurors that Malius Glaucia, a friend of Titus Roscius Capito, travelled to Ameria with relays of light vehicles, rapidly covered fifty six miles in ten hours ${ }^{46}$, he immediately brought the news of this murder to Ameria, not to the son of the murdered man, Roscius Amerinus, but to his enemy T. Roscius Capito. Mallius Glaucia ${ }^{47}$ was identified by Cicero with the mythical Automedon, Achilles, charioteer as to emphasize the speed of Glaucia's journey to Ameria to bear the news of Roscius' death.

Dyck $^{48}$ cites that Cicero's brief allusion, as often in Juvenal ${ }^{49}$, serves to illustrate the chasm between heroic saga and sordid:

Pro Rosc. Amer. 98 
"non suis manibus in curu collocat Automedontem illum, sui sceleris acerbissimi nefariaeque victoriae nuntium".

\section{Conclusion:}

After examining the influence of the Greek myth in Cicero's forensic speech of Pro Roscio Amerino, it can be concluded that Cicero intentionally focused on the insertion of the Greek myth because his main aim was to occlude the jurors' vision in the murder case of Sex. Roscius which was rather weak and lacking strong legal proofs. It is remarkable that there are various uses of the intertextuality existed in this speech as follows: Cicero composed his speech according to the Aristotelian compositional schemes on adapting some mythical tales and characters ${ }^{50}$ mentioned by both the most celebrated Greek epic poet, Homer and the Greek tragedians (Aeschylus, Sophocles, Euripides), and also by the Attic orator, Aischines. He quoted the characters of both Orestes and the avenging Erinnyes from Aischines who had in his turn learnt them from the above mentioned Greek writers. Besides, Cicero, when he was young, learnt in the lessons of rhetoric both the myth of Orestes as a tragic plot and the idea of the avenging Erinnyes as a symbol of stings of conscience presented by the ancient Roman epic writer, Ennius. He also, on talking of the famous mythical and historical characters who were prohibited from fighting, mentioned both a verse ${ }^{51}$ from the Achilles of Ennius, referring to the illustrious Greek hero, Ulysses, and Priamus ${ }^{52}$, the king of Troy. 
A mythological reading of Cicero's Pro Sex.

Notes:

* I seize this opportunity to thank my Prof. Weische, University of Münster who has been always helpful to me, and has provided me with his valuable remarks and advices on supervising my thesis for PhD: "Studies in the Syntactical and Rhythmical Structure of Periods in Cicero's Judicial Speeches".

(1) It is important to cite here that Cicero could expect an audience to respond to the interplay between his mythical tales and characters and those of the Greek tragedians and orators.

(2) Riggsby, A. M., Crime and Community in Ciceronian Rome, p. 64.

(3) Sen. Ep. 49. 12, 115. 14-15; Petron. Satyr. 2; Stat. Sil. 5.3, 146 ff.; Quint. Instit. Orat. 10. 1. 66-8. Greek philosophy, tragedy and literature were always an active and formative ingredient in elite Roman education and culture.

(4) Cic. De Off. 2. 14. 51; Buchheit, V., "Ciceros Kritik an Sulla in der Rede für Roscius aus Ameria". Hermes 24 (1975), pp. 270- 91.

(5) Cic. Brut. 312.

(6) Ibid., Pro Rosc. Amer. 72; Ibid., Orat. 107.

(7) Ibid., Pro Rosc. Amer. 35- 82.

(8) Arist. Poet. 1450 B 25- 6, 33; Ibid., Rhet. III. XIV. XVI. XVII. XIX.

(9) Veyne, P., Les Grecs ont-ils cru à leurs Mythes? essai sur l'imagination constituante-Editions du seuil, p. 64; Louyeleidi, Y., "When Modernism reads Greek Mythology". Class. Pap. Vol. VII. Cairo Univers. (2007), pp. 39- 54.

(10) Chapman, G. A., "Some Notes on Dramatic Illusion in Aristophanes. "AJPh 104 (1984); Burian, P., Myth into Muthos: The shaping of Tragic Plot, pp. 178- 208; Muecke, F., "Playing with the Play: Theatrical Self-Consciousness in Aristophanes". Antichthon" (1977), p. 55 ff.

(11) Sifakis, G. M., Parabasis and Animal Chorus. A Contribution to the History of Attic Comedy, p. $7 \mathrm{ff}$.

(12) Bain, D., Actors and Audience. A study of Asides and Related Conventions in Greek Drama, p. $6 \mathrm{ff}$.

(13) Zadorojnyi, A., "Thucydides 'Nicias and Homer's Agamemnon". Class. Quart. 48 (1998), p. $298 \mathrm{ff}$.

(14) Armstrong, R., "Crete in the Aeneid: Recurring Trauma and Alternative Fate". Class. Quart. 52 (2002), pp. 321- 340; West, S., "Crete in the Aeneid. Two Intertextual Footnotes". Class. Quart. 53 (2003), pp. 302- 307.

(15) Mayer, R., "A Lost Allusion Recovered: Tacitus. Histories 3.37. 1 and Homer. Iliad 19. 301-2". Class. Quart. 53 (2003), pp. 313- 15.

(16) May, J. M., Trials of Character: The Eloquence of Ciceronian Ethos, pp. 21- 2, 31.

(17) Cic. De Off. 2. 14, 15; Buchheit, V., op. cit., pp. 570- 91.

(18) Seager, R. J., "The Political Significance of Cicero's Pro Roscio". LCM 7.1 (1982), pp. 10-12; Kinsey, T. E., "The Political Insignificance of Cicero's". 
LCM 7. 3 (1982), pp. 39- 40.

(19) Cic. Pro. Rosc. Amer. 20, 25, 96-7, 105, 110, 152; Allam, M. Reda K., Dramatic Structure in Cicero's Defense Speech of Sex. Roscius Amerinus". Class. Pap. Vol. VII. Cairo Univ. (2007), p. 283; Riggsby, A. H., op. cit., p. 64, not. 26; Vasaly, Ann, Representations: Images of the World in Ciceronian Oratory, pp., 156- 72.

(20) Stroh, W., Taxis und Taktik, p. 75; Riggsby, A. M., op. cit., pp. 61- 64; Kinsey, T. E., "Cicero's case against Magnus Capito and Chrysogonus in the Pro Sex. Roscio Amerino and its use for the historian". AC 49 (1980), pp. 185- 6; Dyck, A. R., "Evidence and Rhetoric in Cicero's Pro Roscio Amerino: The case against Sex. Roscio". Class. Quart. 53. 1 (2003), pp. 235- 246.

(21) Dyck, A. R., Evidence and Rhetoric, p. 243; Vasaly, A., op. cit., pp. 156- 72.

(22) Cic. Pro Arch. 3; In Pis. 68; Pro Mur. 61.

(23) Ibid., Orat. 113- 120; Ibid., Brut. 322; Ibid., De Orat. I. 5, 17- 8; II. 311- 312.

(24) Zillinger, W., Cicero und die altrömischen Dichter, p. 67; Cic. Pro Leg. Man. 22; Ibid., Pro Rosc. Amer. 46; Ibid., 90: Quis ibi non est vulneratus ferro Phrygio? Ibid., Tusc. Disput. I. 15- 34: Aspicite, Ocives senis Enni imagines formam hic vestrum pinxit maximam facta partum.

(25) Boyle, A. J., Roman tragedy, p. 71.

(26) Quintilian. Instit. Orat. I. 8. 11-2.

(27) Cic. In Verr. 2.1, 28, 106, 145; Ibid., Har. Resp. 20, 39; Ibid., In Pis. 47; Ibid., Pro Sest. 48.

(28) Goldberg, S., "Cicero and the Work of Tragedy". Manuwald (2000), pp. 4959; Vogt-Spira, G. "Ennius' Medea: Eine Fremde in Rom". Manuwald (2000), pp. $265-75$.

(29) Cic. Pro Rosc. Amer. 66, 67, 90, 98.

(30) Petaccia, M. R., "Der Orestes- Mythos in der lateinischen archais römischen Republik". Manuwald (2000), pp. 87- 112; Boyle, A. J., Roman tragedy, pp. 87, 91, 94. Probably Cicero quoted his tale of Orestes from Pacuvius whom he listed as the best tragedian (Cic. Op. Gen. 1. 2). Orestes was mentioned again by Cicero in his speech (Pro Arch. 8).

(31) Jocelyn, A. D., "Ennius as a Dramatic Poet". Fondation Hardt Entretien 17 (1972), pp. 39- 75. Alc. Frag. XV (Jocelyn); Boyle, A. J., op. cit., pp. 58- 9, 67. Probably Cicero quoted his tale of Alcmeo from Ennius whom he listed as the best poet (Cic. Op. Gen. 1. 2).

(32) Weische, A., Nachahmung der attischen Redner, pp. 24-5, 32-3; Laughton, E., Cicero and the Greek Orators". AJPh 82 (1961), p. 34.

(33) Aeschyl. Agam. 747; Ibid., Eum. 334- 340; Pausanias I. 28. 6; Braun, M., Die Eumeniden des Aischylos und der Areopag., p. $15 \mathrm{ff}$. It is noteworthy to cite here that in the Eumenides Aeschylus definitely glorified the Areopagus at a time when Ephialtes and Pericles were removing most of its jurisdiction.

(34) In the trilogy of Aeschylus' Oresteia the avenging Erinnyes were invisible 
= A mythological reading of Cicero's Pro Sex.

in the first two dramas and visible in the third.

(35) Segal, Ch. "Greek Myth as Semiotic". Arethusa 16 (1983), p. 179.

(36) Zeitlin, F., "The Closet of Masks: Role- Playing and Myth- Making in the Orestes of Euripides". Ramus 9 (1980), pp. 52- 6; Erbse, H., "Orestes des Euripides". Hermes 103 (1975), pp. 443- 5.

(37) Burian, P., "Myth into Muthos: The Shaping of Tragic Plot". pp. 178- 208.

(38) Landgraf, G., Kommentar zu Cicero's Rede Pro Sex. Roscio Amerino, obviously and abundantly discussed the avenging Erinnyes in both Greek and Roman dramas.

(39) Skard, E., Sallust und seine Vorgänger, eine sprachliche Untersuchung, p. 65.

(40) Ibid., 66: "da $\beta$ die altrömische Orestes- Tragödie und ihre Auswertung bei Cicero für die Entwicklung des Gewissensbegriff ein bedeutsamer Faktor gewesen sind"; Rudberg, G., Cicero und das Gewissen. Symb. Osl. 31 (1955), pp. 94- 104. it is noteworthy to mention here that the avenging Erinnyes had been also referred to in Cicero's speeches: In Pis. 46 and De Leg. I. 40.

(41) Cic. Pro Rosc. Amer. 89, 90; Crawford, J. W., M. Tullius Cicero: The Fragmentary Speeches, p. $7 \mathrm{ff}$. The prosecutor Erucius was prepared by the two Amerians: Roscius Capito and Roscius Magnus to accuse Sex. Roscius Amerinus of murdering his father; once more he appeared in an another murder case (Pro Vareno), in which Cicero followed the same tactic of foisting the responsibility onto the prosecution to realize his aim.

(42) Cicero compared the sanguinary battles of Cannae and Trasimenus with the massacres of the proscribed near the reservoir in Rome, adjoining the Basilica Iulia, where the heads of the slain accusers had been exposed.

(43) Boyle, A. J., op. cit., pp. 58, 243 n 53.

(44) Ibid., 90.

(45) Ibid.

(46) Ibid., 19, 96-8.

(47) Ibid., 98.

(48) Dyck, A. R., Evidence and Rhetoric, pp. 244- 5.

(49) Schmitz, C., Das Satirische in Juvenals Satiren, p. 248 f.

(50) Cic. Pro Rosc. Amer. 66, 67, 90, 98.

(51) Ibid., 90.

(52) Ibid. 


\section{References:}

- Allam (M. Reda K) (2007), "Dramatic Structure in Cicero's Speech: In Defense of Sex. Roscius Amerinus". Class. Pap. Vol. VII. Cairo University.

- Armstrong (R) (2000), "Crete in the Aeneid: Recurring Trauma and Alternative Fate". Class. Quart. 52, pp. 321- 340.

- Bain (D) (1977), Actors and Audience. A Study of Asides and Related Convention in Greek Drama. Oxford.

- Boyle (A. J) (2006), Roman Tragedy. London and New York.

- Braun (M) (1998), Die Eumeniden des Aischylos und der Areopag. Tübingen.

- Buchheit (V) (1975), "Ciceros Kritik an Sulla in der Rede für Roscius aus Ameria". Hermes 24, pp. 570- 91.

- Burian (P) (1997), "Myth into Muthos: The Shaping Plot". Cambridge.

- Chapman (G. A) (1984), "Some Notes on Dramatic Illusion in Aristophanes". AJPh 104.

- Crawford (J. W) (1994), M. Tullius Cicero. The Fragmentary Speeches. Atlanta.

- Dyck (A. R) (2003), "Evidence and Rhetoric in Cicero's Pro Roscio Amerino: The case against Sex. Roscio". Class. Quart. 53. 1., pp. 23546.

- Erbse (H) (1975), "Orestes des Euripides".Hermes 103.

- Goldberg (S) (2000), "Cicero and the Work of Tragedy". Manuwald, pp. 49- 59.

- Jocelyn (A. D) (1972), "Ennius as a Dramatic Poet". Fondation Hardt Entretiens 17, pp. 39- 95.

- Kinsey (T. E) (1982), "Cicero's Case against Magnus, Capito and Chrysogonus in the Pro Sex. Roscio Amerino and its use for the historian". AC 49.

$\bullet$ (982), "The Political Significance of Cicero's Pro Roscio". LCM 7.3. 194 
- A mythological reading of Cicero's Pro Sex.

(1985), "The Case against Sextus Roscius of Ameria". AC 54, pp. 188- 96.

- Landgraf (G) (1978), Kommentar zu Ciceros Rede Pro Sex. Roscio Amerino. Hildesheim.

- Laughton (E) (1981), "Cicero and the Greek Orators". AJPh 82, pp. 2749.

- Louycleidi (Y) (2007), "When Modernism reads Greek Mythology". Class. Pap. Vol. VII Cairo University, pp. 39- 54.

- May (J. M) (1988), Trials of Character: The Eloquence of Ciceronian Ethos. Chapel Hill.

- Mayer (R) (2003), "A Lost Allusion Recovered: Tacitus. Histories 3. 37. 1 and Homer. Iliad 19. 301- 2". Class. Quart 53.

- Muecke (F) (1977), "Playing with the Play: Theatrical SelfConsciousness in Aristophanes". Antichthon.

- Petaccia (M. R) (2000), "Der Orestes- Mythos in der lateinischen archais römischen Republik", Manuwald, pp. 87- 112.

- Riggsby (A. M) (1999), Crime and Community in Ciceronian Rome. Austin.

- Rudberg (G) (1935), "Cicero und das Gewissen Symb. Osl. 3, pp. 94104.

- Schmitz (C) (2000), Das Satirische in Juvenals Satiren. Berlin.

- Seager (R. J) (1982), "The Political Significance of Cicero's Pro Roscio". LCM 7.1.

- Segal (Ch) (1983), "Greek Myth as Semiotic". Arethusa 16.

- Sifakis (G. M) (1971), Parabasis and Aninal Chorus. A Contribution to the History of Attic Comedy. London.

- Skard (E) (1956), Sallust und seine Vorgänger, eine sprachliche Untersuchung. Oslo.

- Stroh (W) (1975), Taxis und Taktik. Stuttgart.

- Vasaly (Ann) (1993), Representations: Images of the World in Ciceronian Oratory. Berkeley. 
- Veyne (P) (1983), Les Grecs ont-ils cru à leurs Mythes? essai sur l'imagination constituante. Editions du seuil.

- Vogt-Spira (G) (2000), "Ennius' Medea: Eine Fremde in Rome". Manuwald, pp. 265- 75.

- Weische (A) (1972), Nachahmung der attischen Redner. Heidelberg.

- West (S) (2003), "Crete in the Aeneid. Two Intertextual Footnotes". Class. Quart. 53, pp. 302- 307.

- Zadorojnyi (A) (1998), "Thucydides' Nicias and Homer's Agamemnon". Class. Quart. 48.

- Zillinger (W) (1911), Cicero und die altrömischen Dichter. Erlangen. 